\title{
Mekanisme Koping Penyalahguna NAPZA yang Menjalani Rehabilitasi di Institusi Penerima Wajib Lapor (IPWL) At - Tauhid Jepara (Studi Fenomenologi)
}

\author{
Imam Arief Mindiono \\ Program Studi S1 Psikologi Fakultas Psikologi Universitas Semarang \\ drimam.arief@usm.ac.id
}

\begin{abstract}
Abstrak. Latar Belakang :Rehabilitas NAPZA adalah rehabilitasi yang meliputi pembinaan fisik, mental, sosial, pelatihan keterampilan, dan resosialisasi serta pembinaan lanjut bagi para mantan pengguna NAPZA agar mampu berperan aktif dalam kehidupan bermasyarakat. Pelayanan rehabilitasi dirancang untuk meningkatkan proses perbaikan klien yang mengalami gangguan mental dalam mengontrol gejala yang ditimbulkan. Penelitian ini bertujuan mengetahui bagaimana gambaran mekanisme koping Penyalahguna NAPZA yang menjalani rehabilitasi di Institusi Penerima Wajib Lapor (IPWL) At - Tauhid Jepara pada tahun 2018. Penelitian ini menggunakan pendekatan deskriptif kualitatif, dimana data diperoleh menggunakan pedoman wawancara (in depth interview) dengan jumlah partisipan tiga orang yang sesuai dengan kriteria inklusi. Hasil wawancara akan dikategorikan sehingga terbentuklah tema-tema. Hasil dan pembahasan penelitian yaitu partisipan berjumlah tiga orang menunjukan beberapa faktor yang mempengeruhi koping seperti dukungan keluarga, dukungan konselor dan dukungan orang lain serta lingkungan sekitarnya. Mekanisme koping yang digunakan oleh ketiga partisipan yaitu denial dan proyeksi. Hal ini terlihat dari penolakan dan rasa marah saat pertama kali berada di wisma dan setelah proses rehabilitasi berjalan ketiga partisipan mampu menjalani proses rehabilitasi. Dengan adanya dukungan keluarga, konselor, orang lain dan lingkungan, akan menciptakan koping yang adaptif, sehingga selama partisipan menjalani rehabilitasi semakin efektif dan efisien.
\end{abstract}

Kata kunci: Mekanisme Koping, Rehabilitasi 


\section{Pendahuluan}

Gangguan penggunaan Narkotika Psikotropika dan Zat Adiktif Lain (NAPZA) merupakan masalah yang menjadi keprihatinan dunia internasional disamping masalah HIV/ AIDS, kekerasan (violence), kemiskinan, pencemaran lingkungan, pemahaman global dan kelangkaan pangan. Badan Perserikatan Bangsa Bangsa (PBB INICEF), International Drug Control Program, menyatakan pada tahun 2016 jumlah pemakai NAPZA di seluruh dunia telah mencapai 315 juta orang dan sedikitnya 100.000 diantara mereka meninggal setiap tahun 1 .

WHO memperkirakan bahwa jumlah pengguna tembakau sebanyak 1,1 miliyar orang, pengguna alkohol sebanyak 250 juta orang, dan pengguna NAPZA lain sebanyak 15 juta orang diseluruh dunia. Global Burden of Diseases (GBD) yang diakibatkan terkait dengan penggunaan NAPZA adalah sebesar 8,9 \% sedangkan Global Mortality Rate akibat pengguna NAPZA sebesar 12,4 \% dan Disable Adjusted Life Years (DALYs) sebesar 8,9\% 2 .

Berdasarkan hasil survei Badan Narkotika Nasional (BNN) bekerjasama dengan Pusat Penelitian Kesehatan Universitas Indonesia (UI) memperkirakan prevelensi penyalahgunaan NAPZA pada tahun 2016 adalah 3,5 juta orang dimana 1,4 juta orang adalah pecandu dengan angka kematian akibat NAPZA 12.000 orang setiap tahunnya ${ }^{3}$.

Peran penting tenaga kesehatan / konselor dalam upaya menanggulangi penyalahgunaan dan ketergantungan NAPZA di Instalasi Rehabilitasi, salah satunya dengan cara pengobatan dan rehabilitasi. Terapi pengobatan bagi klien NAPZA misalnya dengan detoksifikasi (Hawari, 2003). Pelayanan rehabilitasi dirancang untuk meningkatkan proses perbaikan klien yang mengalami gangguan mental dalam mengontrol gejala dan penatalaksanaan pengobatan meliputi peningkatan kemampuan diri kembali ke masyarakat, pemberdayaan, meningkatkan kemandirian dan kualitas hidupnya4. Rehabilitasi NAPZA adalah suatu bentuk terapi dimana klien dengan ketergantungan NAPZA ditempatkan dalam institusi tertutup selama beberapa waktu untuk mengedukasi pengguna yang berusaha untuk mengubah perilakunya, mampu mengantisipasi dan mengatasi masalah relaps ${ }^{1}$.

Siburian dalam penelitiannya yang berjudul "Pengaruh Rational Emotive Behavioral Therapy (REBT) Dalam Menurunkan Kecemasan Menghadapi Masa Depan Pada Penyalahguna Napza Di Panti Rehabilitasi", survei awal dilakukan dengan menyebarkan 37 angket kepada penyalahguna NAPZA yang sedang menjalani program rehabilitasi ${ }^{5}$. Hasilnya 20 orang menyatakan bahwa mereka mengalami kecemasan selama menjalani program rehabilitasi, dan sisanya mengalami stres dan depresi. Stres merupakan 
tanggapan atau reaksi tubuh terhadap berbagai tuntunan atau beban atasnya yang bersifat non spesifik ${ }^{4}$. Manajemen koping, daya psikologis, optimisme, dukungan sosial, merupakan faktor psikologis yangdapat mengurangi atau menahan stress ${ }^{2}$.

Setiap individu mempunyai mekanisme koping untuk pertahanan dirinya terhadap suatu tekanan atau stresor yang datang. Roy menggunakan istilah mekanisme koping untuk menjelaskan proses kontrol dari individu sebagai suatu sistem adaptasi ${ }^{6}$. Mekanisme koping merupakan mekanisme yang digunakan induvidu untuk menghadapi perubahan yang di terima, apabila mekanisme koping pengguna NAPZA berhasil maka orang tersebut akan dapat beradaptasi terhadap perubahan yang terjadi. Mekanisme koping dapat dipelajari sejak awal timbulnya stresor sehingga individu tersebut menyadari dampak dari stresor tersebut ${ }^{6}$.

Koping merupakan suatu proses dimana individu mencoba untuk mengelola jarak yang ada antara tuntutan- tuntutan (baik tuntutan yang berasal dari individu maupun tuntutan yang berasal dari lingkungan) dengan sumber daya yang mereka gunakan dalam menghadapi situasi yang membuat mereka tertekan?

\section{Metode}

Penelitian ini menggunakan pendekatan deskriptif kualitatif jenis fenomenologi yaitu pendekatan yang dilakukan dengan cara memberi gambaran terhadap objek yang diteliti melalui data sampel atau data populasi. Sampel penelitian ini adalah Penyalahguna NAPZA yang menjalani rehabilitasi di Institusi Penerima Wajib Lapor (IPWL) At - Tauhid Jepara berjumlah 3 partisipan. Penentuan besar sampel dalam penelitian ini menggunakan non probability sampling dengan pendekatan purposive sampling yang ditentukan oleh peneliti saat memasuki lapangan selama penelitian berlansung dengan kriteria inklusi sebagai berikut: partisipan yang sedang menjalani rehabilitasi pertama kali, partisipan yang dapat berinteraksi dengan baik dan partisiapan berbahasa Indonesia dan bersedia menjadi responden sehingga diharapkan mendapat informasi yang optimal.

Instrumen penelitian ini adalah peneliti sendiri, dengan tambahan satu orang asisten dan instrument tambahan seperti note book dan informed concent form, alat perekam serta camera atau video. Metode pengumpulan data yaitu dengan mengobservasi dan melakukan wawancara kepada partisipan yang berada di Institusi Penerima Wajib Lapor (IPWL) At - Tauhid Jepara dengan in-depth interview, atau wawancara mendalam tentang pengalaman pertama kali menjalani rehabilitasi di Institusi Penerima Wajib Lapor (IPWL) At - Tauhid Jepara. 
Pengalaman partisipan saat pertama kali menjalani rehabilitasi merupakan aspek sensitive pada partisipan sehingga diperlukan pertimbangan etik untuk menjamin tidak adanya pelanggaran hak partisipan selama penelitian. Beberapa prinsip etik yang diterapkan dalam penelitian ini adalah beneficience terutama dimensi freedom form harm,justice (prosedur anominity dan confidentiality), dan menerapkan hak selfdetermination.

Metode analisis data yang digunakan pada penelitian ini adalah menggunakan metode intepretasi data Sembilan langkah menurut Collazi, yaitu dengan mendeskripsikan fenomena yang diteliti, mengumpulkan deskripsi melalui pendapat partisipan, membaca seluruh deskripsi fenomena yang disampaikan oleh partisipan, membaca kembali hasil transkrip wawancara dan mengutip pernyataan yang bermakna, menguraikan arti yang ada dalam beberpa pernyataan, mengorganisir kumpulan makna yang terumuskan ke dalam kelompok tema, menuliskan deskripsi yang lengkap, menemui partisipan untuk melakukan validasi diskripsi hasil analisis dan menggabungkan data hasil validasi ke dalam deskripsi hasil analisa.

\section{Hasil}

\section{Karakteristik Responden}

Tabel 1.1 Karakteristik Partisipan

\begin{tabular}{lccc}
\hline Nama & Umur & Pendidikan & Pekerjaan \\
\hline Tn. N & 36 thn & SMP & Tukang Batu \\
\hline Tn. Z & 20 thn & SMA & Pengamen \\
\hline Tn. H & 25 thn & SMA & Buruh Lepas \\
\hline
\end{tabular}

Sumber : Data Primer 2018

\section{Diskusi}

Faktor - faktor pendukung dan penghambat yang memepengaruhi koping yang digunakan Penyalahguna NAPZA yang menjalani rehabilitasi.

Berdasarkan pernyataan partisipan- partisipan, faktor yang muncul selama menjalani proses rehabilitasi di Institusi Penerima Wajib Lapor (IPWL) At - Tauhid Jepara yaitu hanya faktor pendukung berupa dukungan keluarga, konselor-konselor, dan dari lingkungan Institusi Penerima Wajib Lapor (IPWL) At - Tauhid Jepara. Dukungan sangat diperlukan sehingga dapat mengurangi stress dan beban pada Penyalahguna saat masuk 
dan menjalani rehabilitasi. Dukungan keluarga merupakan suatu system pendukung yang diberikan oleh keluarga terhadap anggota keluarga yang meliputi memberikan dukungan emosional, bantuan materil, memberikan indormasi, dan pelayanan, serta memfasilitasi anggota keluarga dalam membuat kontak sosial dalam masyarakat ${ }^{8}$.

Studi tentang dukungan keluarga telah mengkonseptualisasi dukungan sosial sebagai koping keluarga. Baik dukungan-dukungan sosial keluarga yang eksternal maupun internal terbukti bermanfaat ${ }^{9}$. Sama halnya dengan penelitian ini, menurut Sahrazad ${ }^{10}$ menyebutkan bahwa pada awal masuk tempat rehabilitasi semua partisipan merasakan stres atau tertekan. Hal ini dikarenakan pada saat masuk tempat rehabilitasi partisipan langsung putus penggunaan narkoba serta kondisi lingkungan yang berbeda dan mereka merasa tidak bebas untuk menjalani hari- harinya. Selain itu dukungan sangat penting bagi para Penyalahguna, dalam hasil penelitian Isnaini11, menyatakan bahwa lingkungan yang mendukung terutama keluarga sangat berperan dalam proses penyembuhan seseorang yang ketergantungan obat. Hal ini disebabkan, tidak banyak dari mereka yang keinginan sembuhnya datang dari dalam dirinya sendiri, lebih banyak pengguna membutuhkan dukungan orang tua.

Berdasarkan data di atas semua pertisipan memperoleh dukungan dari keluarga dan konselor serta residen Institusi Penerima Wajib Lapor (IPWL) At - Tauhid Jepara. Konselor memberi dukungan pada semua partisipan berkaitan dengan pemberian informasi tentang rehabilitasi, peraturan dan kegiatan selama menjalani proses rehabilitasi. Dukungan anggota keluarga pada semua partisipan yaitu memberikan semangat, nasehat, dan motivasi pada semua partisipan. Hal ini senada dengan penelitian yang dilakukan oleh Darojah ${ }^{12}$, Beragamnya bentuk- bentuk dukungan keluarga yang meliputi dukungan emosional, penghargaan, instrumental, dan informatif menyumbang aksi sugesti yang positif terhadap permasalahan penyalahgunaan napza.

Beberapa orang partisipan mengungkapkan bahwa teman ataupun orang lain disekitarnya juga ikut memberikan dukungannya selama proses rehabilitasi. Sedangkan sumber dan bentuk penghambat yang dirasan oleh partisispan hanya satu yaitu keadaan dimana partisipan pertama tidak merasakan adanya dukungan dari lingkungan sekitar wisma. Menurut Roth mengatakan bahwa dukungan sosial berfokus pada sifat interaksi yang berlangsung dalam berbagai hubungan sosial sebagaimana yang dievaluasi oleh individual. Dukungan yang dimaksud adalah dukungan dari keluarga, orang lain dan lingkungan sekitarnya. Dukungan sosial memasukkan juga evaluasi individu atau keluarga, apakah interaksi/hubungan bermanfaat dan sejauhmana manfaatnya ${ }^{9}$. 


\section{Jenis koping yang di gunakan penyalahguna NAPZA yang menjalani rehabilitasi.}

Berdasarkan pernyataan partisipan- partisipan, terdapat dua jenis koping yang digunakan yaitu jenis koping psikologi dan psiko-sosial. Masing masing dari ke dua jenis koping ini digunakan oleh ke 3 partisipan. Jenis koping psikoligis yaitu bagaimana persepsi atau penerimaan individu terhadap stresor, artinya seberapa berat ancaman yang dirasakan oleh individu tersebut terhadap stressor yang diterimanya, jika strategi yang digunakan efektif maka menghasilkan adaptasi yang baik dan menjadi suatu pola baru dalam kehidupan tetapi jika sebaliknya dapat mengakibatkan gangguan kesehatan fisik maupun psikogisnya ${ }^{13}$.

Berdasarkan penelitian yang didapatkan pada Institusi Penerima Wajib Lapor (IPWL) At - Tauhid Jepara didapatkan pernyataan dari ke tiga partisipan yang mengungkapkan, bahwa tidak pernah merasa sendiri dan diabaikan, kemudaian mampu beradaptasi dengan lingkungan tempat rehabilitasi dengan pernyataan bahwa ada teman bicara dan berbincang bicang pada saat menjalani rehabilitasi. Berdasarkan pernyataan terebut dapat disimpulkan bahwa jenis koping psikologis yang digunakan yaitu mampu menerima stressor dengan strategi efektif yang menghasilkan adaptasi yang baik guna meningkatkan kualitas hidup pada saat melakukan rehabilitasi. Hal ini senada dengan penelitian Noviarini ${ }^{14}$, hasil tersebut menunjukkan bahwa hipotesis penelitian ini diterima, artinya terdapat hubungan positif yang sangat signifikan antara dukungan sosial dengan kualitas hidup, dimana semakin tinggi tingkat dukungan sosial yang dirasakan individu maka tingkat kualitas hidup individu juga tinggi, sebaliknya semakin rendah tingkat dukungan sosial maka semakin rendah pula tingkat kualitas hidup.

Jenis koping psiko-psosial dari beberapa partisipan menggunakan koping ini juga, terlihat adanya usaha prilaku menyerang (fight) yaitu individu menggunakan energinya untuk melakukan perlawanan dalam rangka mempertahankan integritas pribadinya ${ }^{13}$.

Perilaku menyerang yang dilakukan oleh partisipan yaitu marah, kesal dan perilaku emosi lainnya yang dapat merugikan diri sendiri dan orang lain. Setelah beberapa bulan menjalani rehabilitasi partisipan menunjukan perilaku menerima yang merupakan perilaku konstruktif oleh individu untuk menyelesaikan masalah dengan cara kompromi. Kompromi dilakukan dengan cara musyawarah atau negosiasi untuk menyelesaikan masalah yang sedang dihadapi. Kompromi dilakukan dengan adanya tindakan negosiasi dengan cara bercerita, melakukan kegiatan, berdoa dan sholat. Pada penelitian mengenai motivasi partisipan dalam mengikuti kegiatan spiritual motivasi klien ketergantungan NAPZA dalam mengikuti kegiatan spiritual, bisa didapat dari lingkungan baik dari teman- 
teman, mentor, bapak rohani bahkan dari orang tua dan saudara mereka juga mendapatkan pengetahuan baru. Selama mengikuti kegiatan spiritual para responden juga mendapatkan pengalaman dan mempunyai harapan yang meningkatkan motivasi ${ }^{15}$.

\section{Metode koping yang di gunakan Penyalahguna NAPZA yang menjalani rehabilitasi.}

Berdasarkan pernyataan partisipan- partisipan, metode koping yang digunakan adalah metode koping jangka panjang. Metode jangka panjang adalah cara ini konstruktif dan merupakan cara yang efektif dan realistis dalam menangani masalah psikologis untuk kurun waktu yang lama ${ }^{13}$. Data yang di dapatkan adalah pernyataan partisipan untuk menanggapi stressor yang ada dengan Berbicara dengan orang lain "curhat" (curah pendapat dari hati ke hati) dengan teman, keluarga, atau profesi dengan masalah yang sedang dihadapi, dan mencoba menerima informasi lebih banyak tentang masalah yang sedang dihadapi, melakukan latihan fisik untuk mengurangi ketegangan/ masalah, membuat berbagai alternatif tindakan yang mengurangi situasi stress. Situasi stres dapat menyebabkan Penyalahguna merasa tidak nyaman selama menjalani rehab, penelitian lain menyebutkan bahwa pada awal masuk tempat rehabilitasi semua partisipan merasakan stres atau tertekan, serta kondisi lingkungan yang berbeda dan mereka merasa tidak bebas untuk menjalani hari-harinya ${ }^{10}$. Purwanta ${ }^{16}$, bahwa terdapat hubungan antara dukungan sosial dengan peningkatan kesehatan dengan diberikannya dukungan dari orang-orang yang berarti bagi pasien dan dengan cara memberikan pendidikan kesehatan pada pasien seperti mengeksplor perasaan, empati, membuka diri, memberi kehangatan, berdampak pada peningkatan kualitas hidup pasien.

Hal senada juga di ungkapkan oleh partisiapan dengan berbicara dan "curhat" (curah pendapat dari hati ke hati), bertukar informasi dengan teman, keluarga, atau profesi dengan masalah yang sedang dihadapi. Menurut House ${ }^{17}$ mengemukakan bahwa dukungan informasi memberikan saran, informasi. Aktifitasnya seperti: bertukar pikiran memberikan pendidikan kepada anggota keluarga yang sakit, informasi dukungan kelompok dan dukungan kepada individu. Partisipan mencoba menerima informasi lebih banyak tentang masalah yang dialami, sehingga partisipan merasa nyaman dan perasaan menjadi damai. Hal tersebut menunjukan bahwa dukungan keluarga, social-emosional dan teman- teman dapat membantu Penyalahguna selama proses rehabilitasi. Dukungan sosial- emosional menurut Kaakinen ${ }^{17}$ mengemukakan bahwa dukungan emosional dapat berupa cinta, kasih sayang, perhatian, simpati, dan pikiran positif. Aktifitasnya dapat berupa mendengarkan, memberikan pujian, memberikan kehadiran. 


\section{Mekanisme koping yang di pakai Penyalahguna NAPZA yang menjalani rehabilitasi.}

Berdasarkan pernyataan partisipan, mekanisme koping yang digunkan pada masa rehabilitasi adalah proyeksi dan denial. Denial merupakan sikap penyangkalan dari partisipan terhadap suatu masalah. Proyeksi merupakan suatu bentuk rasa tanggung jawab pada diri sendiri terhadap masalah yang di hadapi 6 .

Pernyataan semua partisipan yang menunjukan adanya mekanisme koping denial yaitu sikap tidak terima berada pada saat berada di wisma, dan merupakan sikap penyangkalan dari partisipan. Sama halnya dengan penelitian yang dilakukan oleh Sahrazad $^{10}$ penelitian lain menyebutkan bahwa pada awal masuk tempat rehabilitasi semua partisipan merasakan stres atau tertekan serta kondisi lingkungan yang berbeda dan mereka merasa tidak bebas untuk menjalani hari-harinya. Depresi juga sering dialami pada penyalahgunaan NAPZA merupakan satu kondisi yang mendasari terjadinya penyalahgunaan tersebut. Depresi dapat pula sebagai akibat perlakuan yang diterima responden tersebut dari masyarakat sekitarnya. Hal ini senada dengan hasil Riset Kesehatan Dasar tahun 2007 yang menghasilkan bahwa prevalensi nasional gangguan emosional pada penduduk yang berumur $\geq 15$ tahun adalah 11,6\% dan di DKI Jakarta mencapai 14,1\% dari 14 provinsi yang dilakukan survey self reported quetionary.

Pernyataan partisipan yang menunjukan adanya mekanisme koping proyeksi yaitu sebuah sikap menyadari atas apa yang telah di perbuat, bertanggung jawab atas apa yang dilakukan oleh individu tersebut. Bentuk pertanggung jawaban Penyalahguna Napza terhadap perilakunya seperti yang di ungkapakan partisipan satu (P1), yaitu sadar, mau menerima konsekwensi terapi. Hal tersebut menunjukan bahwa para Penyalahguna harus tetap menjalani terapi yang rutin salah satunya adalah terapi rumah methadone. Setiyawan ${ }^{18}$, dalam penelitiannya secara bahwa keluarga merupakan factor pendukung bagi para pencandu dalam menjalani proses terapi di rehabilitasi. Dalam hal ini fungsi keluarga mepunyai pengaruh terhadap kepatuhan Penyalahguna dlam menjalani terapi.

\section{Dampak yang dirasakan Penyalahguna NAPZA yang menjalani rehabilitasi.}

Berdasarkan pernyataan beberapa partisipan menunjukan dampak positif seperti pernyataan partisipan 1, mendapat kepercayaan, badan menjadi sehat, dapat berpikir jernih dan mengambil keputusan. Senada dengan partisipan 2 dampak positif yang ia rasakan seperti mengetahui baik dan buruk dari barang-barang seperti itu (NAPZA), dapat diterima oleh masyarakat kembali. Pernyataan positif juga diungkapkan oleh pertisipan 3 seperti, dapat menemukan jati diri (lebih percaya diri), dan mau menjauhi barang- barang itu (NAPZA). Partispan 3 merasakan ada dampak negative yaitu ia merasakan keadaan 
jauh dari keluarga.

\section{Harapan Penyalahguna NAPZA yang menjalani rehabilitasi.}

Harapan Penyalahguna napza selama menjalani proses rehabilitasi merupakan tujuan khusus yang terjawab dalam tema harapan selama selama menjalani rehabilitasi. Harapan selama proses rehabilitasi tergambar pada satu kategori yaitu keinginan saat rehabilitasi selama di Institusi Penerima Wajib Lapor (IPWL) At - Tauhid Jepara. Berdasarkan hasil penelitian di Institusi Penerima Wajib Lapor (IPWL) At - Tauhid Jepara terungkap bahwa sejumlah harapan partisipan selama menjalani rehabilitasi yaitu partisipan berharap ingin berkumpul kembali bersama keluarga dan masyarakat, dapat melakukan aktivitas seperti biasa.

Snyder ${ }^{19}$ menyatakan harapan adalah keseluruhan dari kemampuan yang dimiliki individu untuk menghasilkan jalur mencapai tujuan yang diinginkan, bersamaan dengan motivasi yang dimiliki untuk menggunakan jalur-jalur tersebut. Harapan merupakan keinginan seseorang tentang peran orang lain dalam suatu kondisi. Harapan individu menentukan bagi mereka apa yang harus dilakukan dalam berbagai keadaan. Masingmasing individu yang terlibat harus merasakan satu tujuan dengan peran-peran yang lain. Harapan pada Penyalahguna napza dalam menjalani rehabilitasi merupakan keingian dari dalam hati, harapan segera ingin bertemu dan berkumpul dengan keluarga.

\section{Kesimpulan}

Faktor-faktor yang mempengaruhi koping yang digunakan Penyalahguna NAPZA yang berada di Institusi Penerima Wajib Lapor (IPWL) At - Tauhid Jepara ialah berupa faktor pendukung dan penghambat. Factor pendukung yang dirasakan oleh partisipan seperti adanya dukungan keluarga, dukungan para konselor dan dukungan dari orang lain serta lingkungan selama menjalani proses rehabilitasi.Jenis koping yang digunakan Penyalahguna NAPZA yang berada di Institusi Penerima Wajib Lapor (IPWL) At - Tauhid Jepara adalah koping psikologis dan psikososial. Koping psikologis dimana Penyalahguna mampu mnghadapi stressor yang datang dengan proses adaptasi yang baik. Koping psikososial yaitu dimana pada proses menjalani rehabilitasi ada respon menyerang (fight) dan respon kompromi pada kenyataan yang ada.

Metode koping yang digunakan individu Penyalahguna NAPZA yang berada di Institusi Penerima Wajib Lapor (IPWL) At - Tauhid Jepara yaitu metode jangka panjang, dimana cara ini konstruktif dan merupakan cara yang efektif dan realistis dalam menangani 
masalah psikologis dari Penyalahguna NAPZA yang menjalani rehabilitasi. Mekanisme koping yang digunakan individu Penyalahguna NAPZA yang berada di Institusi Penerima Wajib Lapor (IPWL) At - Tauhid Jepara adalah denial dan proyeksi. Denial dimana individu menyangkal keberadaannya, tidak menerima kenyataan yang sedang dihadapinya, kemudian beralih pada mekanisme koping proyeksi yaitu dimana individu berusaha untuk bertanggung jawab atas apa yang telang dilakukannya, dan sepantasnya mendapat apa yang seharusnya di dapatkan dari perbuatannya.

Dampak yang dirasakan Penyalahguna NAPZA yang menjalani pengobatan di rehabilitasi Institusi Penerima Wajib Lapor (IPWL) At - Tauhid Jepara ialah berupa dampak positif yang membangun bagi para Penyalahguna yang menjalani proses rehabilitasi. Dampak negatif yang dirasakan hanya merasa jauh dari keluarga. Harapan pasien selama menjalani rehabilitasi Institusi Penerima Wajib Lapor (IPWL) At - Tauhid Jepara adalah ingin kembali hidup seperti khalayak, hidup dengan baik, di terima di masyarakant, dan mampu menemukan jati diri berupa kepercayaan diri kembali.

\section{Daftar Pustaka}

Sumiati (2009). Asuhan Keperawatan Pada Klien Penyalahgunaan dan Ketergantungan NAPZA. CV Trans Info Media : Jakarta .

Kemenkes R. I. (2010). Pedoman Layanan Terapi dan Rehabilitasi Komperhensif Pada Gangguan Pengguna NAPZA Berbasis Rumah Sakit.

BNN \& Universitas Indonesia, Survei Penyalahgunaan dan Peredaran Gelap Narkoba Pada Kelompok Pelajar dan Mahasiswa di 18 Provinsi Tahun 2016

Yosep, Iyus, S.kp, M. Si. (2009). Keperawatan Jiwa, edisi revisi., Bandung: PT. Refika Aditama.

Siburian, E., dkk. (2010). Pengaruh rational emotive behavioral therapy (REBT) dalam menurunkan kecemasan menghadapi masa depan pada penyalahguna napza di panti rehabilitasi. Jurnal Psikologi UNDIP, (7), (1).

Nursalam, (2008). Konsep dan Penerapan Metodologi Penelitian Ilmu Keperawatan; pedoman skripsi, tesis, dan instrument penelitian keperawatan. Salemba Medika : Jakarta .

Wade, Carole, dan Carol Tavris. (2007). Psychology, 9th edition, bahasa Indonesia language edition. Jakarta: Penerbit Erlangga

Kusuma, H. (2011). Hubungan Antara Depresi dan Dukungan Keluarga dengan Kualitas Hidup Pasien HIV/AIDS yang Menjalani Perawatan di RSUPN Cipto Mangunkusumo Jakarta (Thesis).

Friedman. M.M. (1998). Keperawatan keluarga: Teori dan praktik (edisi 3).Jakarta: EGC

Sharazad, S. 2007.Stress dan Coping Stress Pada Penyalahguna Dewasa Awal yang Sedang Menjalani Rehabilitasi. Universitas Tarumanagara. Fakultas Psikologi. Jakarta. (Skripsi) 
Isnaini, Y., dkk. (2011). Hubungan antara dukungan keluarga dengan keinginan untuk sembuh pada penyalahguna napza di lembaga pemasyarakatan Wirogunan Kota Yogyakarta. Jurnal Kesehatan Masyarakat. 5 (2), 162-232

Darojah, Z. (2008). Pendekatan family support group dalam pemulihan korban penyalahgunaan napza Panti Sosial Pamardi Putra "Sehat Mandiri" Yogyakarta. Skripsi

Rasmun (2004). Stres, Koping, dan Adaptasi. Sugeng Seto : Jakarta.

Novariani, N.A., dkk. (2013). Hubungan antara dukungan social dengan kualitas hidup pada pecandu narkoba yang sedang menjalani rehabilitasi. Prceeding PESAT. 5. Pp 117-122.

Supartina, P. 2007. Motivasi Klien Ketergantungan NAPZA Dalam Mengikuti Kegiatan Spiritual di Rehabilitasi Rumah Damai Desa Cepoko Kec. Gunung Pati Kodya Semarang. Universitas Diponogoro. Fakultas Kedokteran. Prodi Keperawatan. Semarang. (Skripsi)

Purwanta. (2006). Hubungan dukungan sosial dengan tingkat depresi pasien yang menjalani terapi hemodialysis. Jurnal I-lib UGM

Kaakinen, J.R., Duff, V.G., Coehlo, D.P., \& Hanson, S.M.H. (2010). Familiy health care nursing: Theory, practice, and research (edition 4). Philadelphia: F.A. Davis Company

Setiyawan, B.A. (2007). Hubungan antara fungsi keluarga dengan kepatuhan berobat pasien program terapi rumatan metadon RSU DR. Soetomo Surabaya. Jurnal Psikiatri.

Snyder, C.R. (2000). Hypothesis: There is Hope. In C.R. Snyder (Eds.), Handbook of HopeTheory, Measures and Applications (pp.3-21). San Diego: Academic Press 